\title{
Research on the Investment Value of Sainsbury's
}

\author{
Bowen Xiao ${ }^{1, a^{*}}$, Qian $\mathrm{Chen}^{2 \mathrm{~b}}$, Ziyang $\mathrm{Yu}^{3 \mathrm{c}}$ \\ ${ }^{1}$ Cass Business School City, University of London London, the United Kingdom \\ ${ }^{2}$ School of Management University College London London, the United Kingdom \\ ${ }^{3}$ International School of Economics and Management Capital University of Economics and Business \\ $a^{*}$ Corresponding author.Email: bowen.xiao@cass.city.ac.uk \\ $b^{*}$ Corresponding author.Email: uceiqc1@ucl.ac.uk \\ $c^{*}$ Corresponding author. Email: yuzy0821@126.com \\ *These authors contributed equally.
}

\begin{abstract}
This paper provides an analysis and evaluation of the market position and approximate future development of Sainsbury's. Value investing strategy is used to examine if it is a good decision to invest in Sainsbury's. The news about the firm's failed merging with Asda and the effect of Coronavirus and Brexit is analyzed. Additionally, the share price is also discussed, and the reasons why Sainsbury's tends to attract fewer investors currently are explained. The paper finds the prospects of Sainsbury's in its current position, focusing on comparative performance in the area of profit margins, share price, expenses, and so on, particularly. We compared Sainsbury's with Tesco. The profitability of Sainsbury's is not as good as the other. The stock prices of these two companies are almost equivalent. Therefore, we concluded that Sainsbury's is far behind Tesco. Results of data analyzed were shown in this paper, and according to the financial statement, we concluded the current and future development trend of the Sainsbury's. With the macroeconomics theories, it can be found that the UK narrowly missed a recession, yet Sainsbury's still plans to close down part of its stores in order to reduce its cost. Sainsbury's is in a market of oligopoly, with the advantage that other companies can hardly entry. We also did a questionnaire about customers' satisfaction in different supermarkets, and found the ranking compared with other stores like Tesco and ASDA. In addition, we discussed the development of online stores during the pandemic which may attract customers in the future, leading to a further decline in traditional supermarket brand's market share unless they adapt.
\end{abstract}

Keywords: Value investing, stock price, sainsbury's, COVID-19, Brexit, profitability ratios

\section{INTRODUCTION}

The world's stock market has recovered from the pandemic to a new height. The longest stock market rally in history was hit hard by the Coronavirus Disease 2019 (COVID-19) pandemic, but recovered in record time to post new highs. However, when it comes to whether to invest in a particular company, investors and scholars may hold different views. Value investment is a kind of investment paradigm, which originates from the thought of Benjamin Graham and David Dodd [1]. The main idea is to select stocks that appear to be trading for below their intrinsic value, which was argued by the supporters, including Warren Buffett, chairman of Berkshire Hathaway. The difference between stock price and intrinsic value is called the margin of safety [2]. Market price does not always reflect the intrinsic value of stocks, because market may overreact to good and bad news, and investors' herd mentality can aggravate this problem. Value investing requires us to conduct in-depth research on the company. This thesis focuses on the analysis of Sainsbury's performance and its future prediction.

Sainsbury's, as the second biggest retailer in the UK, has entered grocery, bank, furniture, and clothing market. Since the failure of the merger with ASDA in 2019, the stock price of the company has gone through a big fall, followed by a sharp rise due to the quantitative easing policy. However, the outbreak of COVID-19 is a great shock to the whole British economy and has changed people's lifestyle and industrial structures to a certain extent. For example, people tend to buy daily necessities and food online rather than in physical stores. This external condition prompted those large retailers to develop online supermarkets. At the same time, considering the impact of Brexit, there are many 
uncertainties in the UK market. However, this market environment also brings opportunities for the recovery and development of Sainsbury's. A company with a good policy to deal with the epidemic is likely to gain more market share.

The main idea of the paper is to use value investing to help investors clarify whether Sainsbury's is suitable for investment and the current circumstances among supermarket industry. This article will clearly discuss Sainsbury's operation and the impact of the market environment through qualitative and quantitative analysis, which will help investors to predict the future development of the company. This study is a good example of value investing, and is also applicable to the supermarket industry. Finally, this paper will make a judgment and summary on whether it is suitable to invest in Sainsbury's company.

\section{DATA AND METHOD}

\subsection{Data}

The main data of the paper includes some valuation and profitability ratios, which are obtained from Sainsbury's annual report and London Stock Exchange. This database is based on two leading enterprises in supermarket industry -Tesco and Sainsbury's. According to their financial annual reports, we can get several basic data, such as stock price, earnings per share, share outstanding, short-term and long-term debt, cash, EBITDA. We calculated P / E, EV / EBITDA, GP / Asset, and EPS growth rates for comparison. The reason for choosing EPS for two years is to calculate the EPS growth rate to test the stability of Sainsbury's.

\subsection{Method}

The central idea for this thesis is value investing. Both qualitative and quantitative analysis are used in the research. First, the study aims to come out the conclusion by using SWOT analysis, which is a typical model in financial field. By investigating and analyzing the market share, the fixed position of the customer in the market, and the scope of business, the results of the measures are compared with other companies in the supermarket industry for analysis. Second, data of market shares per year are presented, which is a standard to judge Sainsbury's performance. Additionally, the change of revenue, dividend yield, and share price are used in the paper as a result of internal factor of integration. Third, in terms of value investing, GP/Asset, EV/EBITDA, P/E and a dividend yield of Sainsbury's are indices that can influence investment choice for the company, compared with the value of their biggest competitors-Tesco.

To be more specific, these formulas will be used in the calculation.

For Sainsbury's,

$$
\begin{aligned}
& \text { Price }- \text { Earnings } \operatorname{Ratio}(\mathbf{P} / \mathbf{E})==\frac{\text { Share price }}{\text { Earnings per share }}=\frac{252.9 \text { pence }}{5.8 \text { pence }}=43.6 \\
& \text { EV } / \text { EBITDA }=\frac{\text { Market value }+ \text { Long term debt }+ \text { Short term debt }- \text { Cash }}{\text { EBITDA }} \\
& =\frac{£ 2,235 * 2,217 \text { million }+£ 2,728 m+£ 4,486 \text { million }-£ 994 m}{£ 1,716 m}=6.51 \\
& \text { GP } / \text { Assets }=\frac{\text { Gross profits }}{\text { Assets }}=\frac{£ 2,016 \mathrm{~m}}{£ 27,937 \mathrm{~m} * 100 \%}=7.22 \% \\
& \text { Growth rate of EPS }=\frac{E P S(2020)-E P S(2019)}{E P S(2019)} \\
& =\frac{5.8 \text { pence }-7.6 \text { pence }}{7.6 \text { pence }} * 100 \%=-23.68 \% \\
& \text { Dividend yield }=\frac{\text { Total dividend yield }}{\text { Number of shares outstanding }}=\frac{£ 109 \text { million }}{2,217 \text { million }}=4.9 \%
\end{aligned}
$$

For Tesco,

$$
\begin{aligned}
& \text { Price }- \text { Earnings Ratio }(\mathbf{P} / \mathbf{E})=\frac{\text { Share price }}{\text { Earnings per share }}=\frac{244.9 \text { pence }}{9.99 \text { pence }}=24.51 \\
& \text { EV } / \text { EBITDA }=\frac{\text { Market value }+ \text { Long term debt }+ \text { Short term debt }- \text { Cash }}{\text { Lat }} \\
& =\underline{£ 2,355 * 9,793 m+£ 8,045 m+£ 10,736 \text { million }-£ 3,408 m} \\
& =8.94 \\
& \text { GP } / \text { Assets }=\frac{\text { Gross profits }}{\text { Assets }}=\frac{£ 4,580 m}{£ 52,302 m * 100 \%}=8.76 \% \\
& \text { Growth rate of EPS }=\frac{E P S(2020)-E P S(2019)}{E P S(2019)} \\
& =\frac{9.99 \text { pence }-13.13 \text { pence }}{13.13 \text { pence }} * 100 \%=-23.91 \% \\
& \text { Dividend yield }=\frac{\text { Total dividend yield }}{\text { Number of shares outstanding }}=\frac{£ 419 \text { million }}{9,793 \text { million }}=4.28 \%
\end{aligned}
$$




\section{MARKET EVALUATION AND COMPETITIVENESS}

When distinguishing whether Sainsbury's is a good investment option or not, one of the mainly used evaluation models is SWOT. Four main characteristics are considered and analyzed by this model: strength, weakness, opportunity, and threat. This model will focus on all of them and describe them deeply with recent events and analysis. We use SWOT to compare the internal and external strengths and weaknesses of Sainsbury's, and better understand its potential opportunities and threats.

\subsection{Strength}

Strengths are referring to capabilities that organizations have when achieving their objectives, while weaknesses encompass limitations and insufficiencies that restrict the company's ability to achieve these objectives.

Sainsbury's is in a market of oligopoly. A few competitors like Tesco, Aldi and Morrisons are sharing the grocery market with Sainsbury's. The advantage is few people can enter the market because of barriers of entry. As one of the biggest super-markets in the UK, Sainsbury's is always supported with huge amounts of money with leading companies among food industry and retailers. Secondly, Sainsbury's also conducted with strong price control, which focused on cost-effective strategy [3]. It's not rational to make differentiation among supermarkets. Additionally, considering competitors of Sainsbury's, Tesco, ASDA and Cooperative are the top ones. They have almost the same customer segmentation and sell nearly identical products. Competition with Waitrose and Marks \& Spencer is less intense for Sainsbury's as they are actually targeting customers who have higher incomes and are willing to buy more expensive products. According to questionnaires, the staff of Sainsbury's are normally more friendly than Tesco or ASDA. This is also one of the strategies used by Sainsbury's to compete with others. Furthermore, based on Marketing Week in 2002, Sainsbury's also corporate with their suppliers. With huge amounts of corporative suppliers, Sainsbury's adopted small profits and quick turnover to attain mutual benefit, which also maintains sustainability. To develop loyal customers, Sainsbury's established its own food brand with the same name with lower prices by comparing it with the market price to attract more consumers to strengthen brand loyalty [4].

In terms of ethical position and corporate Social Responsibility, Sainsbury's says that they are committed to ethical trading, sourcing its products with integrity avoiding waste. Also, before buying from suppliers, they ensure that the farms in all 70 countries they buy from are not involved in modern-day slavery or trafficking by vetting each farm and providing workshops for employers to help them avoid it [5]. Sainsbury's also aims to protect seasonal worker's rights after being exposed in 2015 for buying from suppliers in the UK who took advantage of eastern European workers. They claim that their training of suppliers has helped them obtain a $75 \%$ return rate of agency workers from abroad.

The Independent newspaper partnered with 'Ethical Consumer' to do an analysis of the 22 largest Supermarket's sustainability and ethics. They ranked Sainsbury's $11 / 20$, joint with M\&S, which put them high up in the rankings compared to most others. The results are as follows: Joint 2nd in Animal Welfare, 2nd in sustainably sourced fish, Top 4 for avoiding Palm oil products and Top 6 for sourcing sustainable timber.

\subsection{Weakness}

In comparison to one of their strongest directcompetitors --- Tesco who offered more choices at similar prices, Sainsbury's is being reduced to absolute inferiority. In the opposite sense of Sainsbury's advantages in the market, it also owned many weaknesses at the same time. First of all, according to Figure 1, the market shares of those giants have hardly changed in recent years. Regardless of the attributes of this market, since Sainsbury's is a mature company selling many necessaries which is not greatly affected by economic growth, it often has a relatively stable profit. However, Sainsbury's is now moderately bad, with some decreases in both market share and profits. 


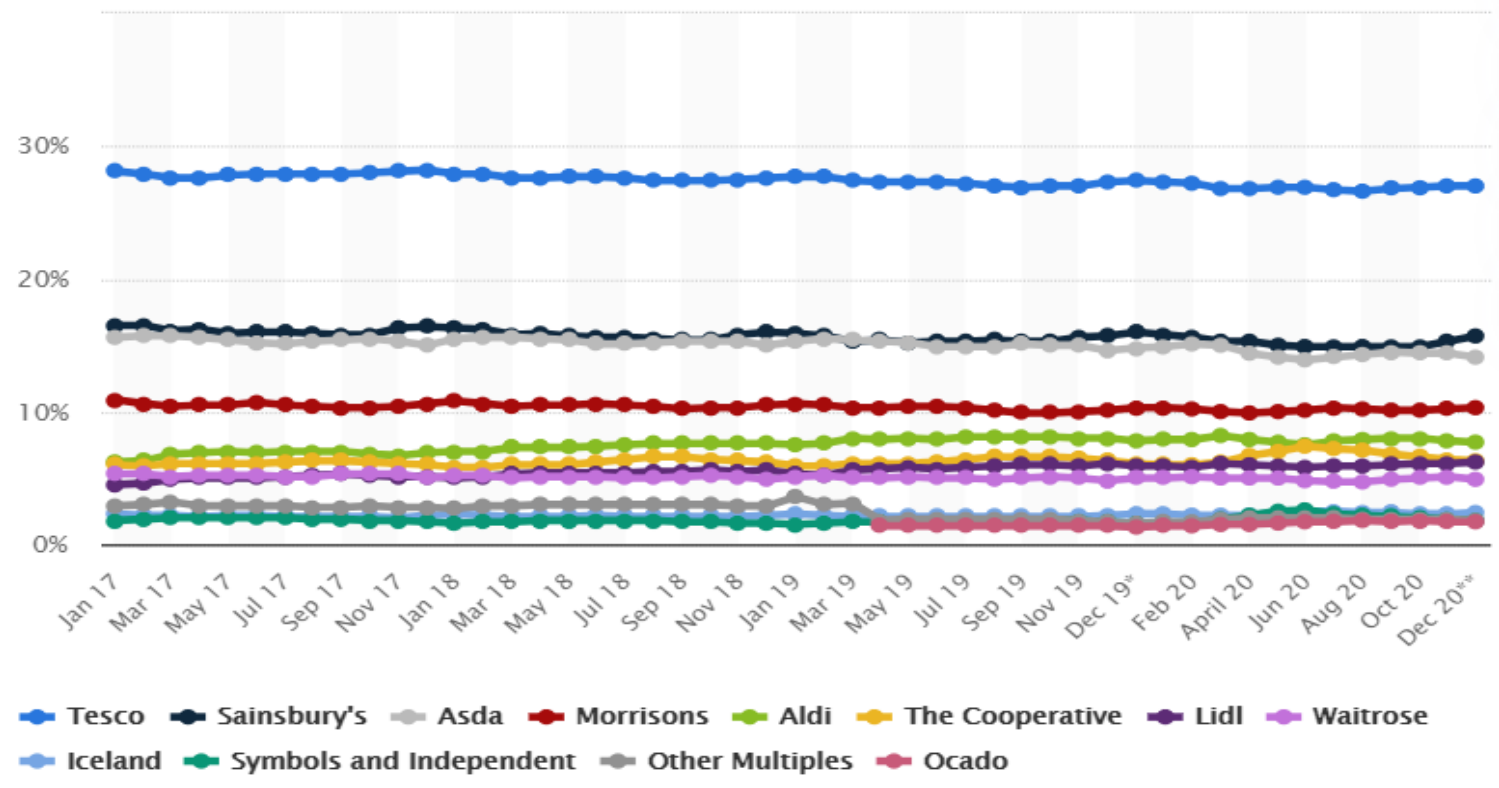

Figure 1. Market share of grocery stores in Great Britain from January 2017 to December 2020.

Online retailers, such as Ocado and Amazon Fresh, are drawing customers away from traditional supermarkets by offering convenient deliveries direct to customer's homes at any time they wish. Online grocery shopping climbed to a new record market share of $13.5 \%$, and Ocado has benefitted most from this trend, reaching its new market share of $1.8 \%$ over the past 12 weeks after yearly growth remained well above $40 \%$ [6]. Although due to the outbreak, Sainsbury's has developed its online supermarket business and has taken actions such as increasing the number of home delivery and click and collect slots available and are on track to offer 750,000 weekly slots. Sainsbury's has lost a lot of its market share, dropping nearly one percentage point after growth of $10.9 \%$ over the past 12 weeks, down from $13.5 \%$ and $12.5 \%$ in previous outings.

Apart from the external influences, internal aspect is also being judged by the public. Criticism towards Sainsbury's treatments of its employee's rights has led the company to gain numerous negative headlines through various social media. Many customers who used to choose Sainsbury's have shifted their preferences to other super-markets instead, which dramatically cut own Sainsbury's revenue and profit.

\subsection{Opportunity}

Opportunities refer to those possible changes or adaptations in the environment surrounding the business, which could be capitalized on to increase its competitive advantage and profitability.

Apart from Sainsbury's itself through discussing strengthens and weaknesses, opportunities and threats are also essential factors that need to be valued among the whole industry. The macro and microenvironment surrounding the changing taste preferences of today's consumers provides opportunities for Sainsbury. One opportunity is moving from innovation. Innovative products and services are always in demand with people's continuous changes on transformations of time. According to Fearne's investigation in 2005, making these new-required products available to customers gives Sainsbury's an opportunity to out-muscle its opponents, whatever through contributing more efforts in its own brand or getting more novel goods from its corporative suppliers [7]. Meanwhile, there is a growth of requirements on delivery orders-to-home. Although Sainsbury's has lost some market share in the online market competition, it is paying more and more attention to the development of online supermarket and is expected to regain the lost market share through its own brand effect in the future.

Brexit will offer Britain companies a vital opportunity to do free trading with any country. EU members have a common trade policy and any trade negotiations can only be carried out for the coalition as a whole. Bloom, Draca and Van Reenen claim that after leaving the EU, Britain will become an independent player and free to expend its trade to the rest of the world without imposed constraints.

In this respect, with the implementation of Brexit, the UK companies, including Sainsbury's will probably increase trade and gain more chances to stand out from the international competition. For example, with the corporation in China, Sainsbury's has built its online store with direct selling from factory outlets, and this store has brought significant profits to Sainsbury's by selling local and special products even under the current situation with Covid-19 [8]." 


\subsection{Threat}

Threats are those external and internal factors that may be detrimental to the healthy growth of the business. Innovations will lead to higher levels of competition from not only products themselves but also capabilities on 'design and imagination'. This could make product range expansion difficult and would be detrimental to profits. To be specific, the intense competition that includes new services among the whole industry may require Sainsbury's to attain a level that untouchable. This condition may cause Sainsbury's fall into a disadvantage, because one of their major competitors --- Tesco has launched a delivery service with the advantage of 'free one-hour deliveries' with substantial workers to undercut the competition [3]. Because Tesco's amazing problemsolving ability, more customers may choose Tesco instead of Sainsbury's. And with uncertainty between suppliers and Sainsbury's, whether Sainsbury's is ready to adapt to changing preferences and establishing efficient connections with partners (each supplier) together to satisfy customers' requirements is questionable.

The examples will make illustration on this principle clearer. J Sainsbury PLC, the parent company of Sainsbury's, used to plan for acquiring Asda Group Ltd., another giant among supermarkets in the United Kingdom. The purpose of this transaction is to make the company the largest grocery retailer in the UK. When Sainsbury's announced this plan in 2018 and listed this new message directly on their official website, it promised a discount on "daily necessities" by at least $10 \%$. With the fermentation of Brexit and the continuously falling of GBP's exchange rate, the Britain's whole supermarket chain has bound to reduce prices as soon as they possibly can. Especially, companies with international business and foreign trade have been forced to suffer a substantial reduction in their profits due to the 'depreciation' of their money in hand (pound). This used to be an opportunity, which might drive stock prices to unprecedented heights, and they stated this prospect on their yearly financial report.

However, in September of the same year, the Competition and Markets Authority (CMA) launched an investigation into Sainsbury's acquisition. CMA estimated that Sainsbury's and Asda would probably close 28-54 stores if they passed this proposal, and this proposal will enable Sainsbury's to be the monopoly in this industry and directly resulting in the layoffs. However, due to the rejection by the UK regulators, a steep share's sell-off has taken place among those 'panicked' Sainsbury's. The collapse of Sainsbury's acquisition brought with a loss of 46 million pounds and put the whole Sainsbury's under pressure, which was informed in the article from Weber and Calvi in the 2010 [9].
Additionally, the negative impacts of Brexit on UK business should also be considered. Britain companies such as Sainsbury's lost access to the single market -most European companies.

Since EU is the main trade partner for the UK, and Brexit results in higher trade barriers and let Sainsbury's and other British companies lose access to the EU Internal Market to a certain degree. The recent study proposed by Antuo in 2016 evaluates that losing access to the single market will cause the Britain's incomes to decline by around $10 \%$ or more based on a general tradeincome relationship [10]. With gradually losing market share in this single market, Sainsbury's may lose its competitive power to an unknown degree.

\section{COMPANY PERFORMANCE}

\subsection{Historic growth of Sainsbury's shares}

Before the 2008 financial crisis, the Sainsbury's share price fluctuated significantly due to changes in management, reluctance to adapt and increased competition.

The management team during the 90 s recession, did not suspect there would be a great deal of damage done to sales revenues as their main source of sales were groceries and packaged foods, which are necessities that are purchased regardless of the economic situation. They were correct in assuming so, and the firm's market share increased from $16.3 \%$ in 1990 to $19.5 \%$ in 1992 when the post-recession economy was recovering. This made them market leaders by a significant $2.3 \%$.

In 1995 Sainsbury's had a market share of $19.1 \%$ compared to $20.8 \%$ for Tesco, from 1994 onwards, the market share decreases nearly every year since at an average rate of $-0.1205 \%$ a year (see Figure 2 ).

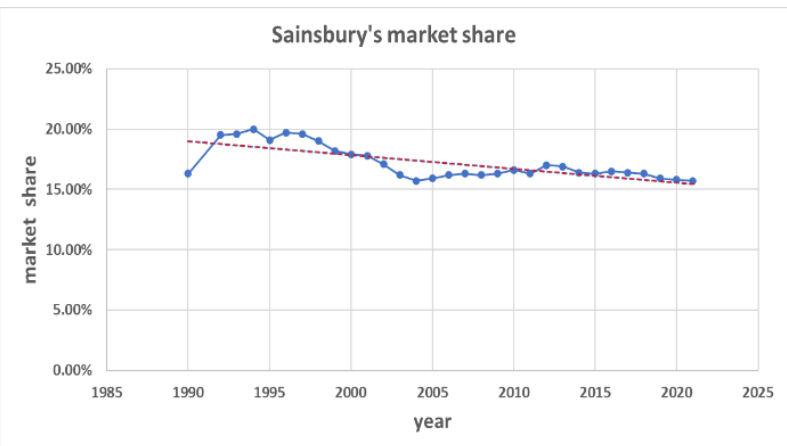

Figure 2. Market share of Sainsbury's - created on Excel using data found in UK \% market share of supermarkets - Groceries market.

There were more dips in the share price in 2003 , 2008, 2014 and 2019. They were caused by increasing debts, a global financial crisis (GFC), and a decrease in sales (both 2014 and 2019), respectively. 


\subsection{Current performance}

Sainsbury's has been in a very tumultuous financial situation since the financial crisis. Their shares have fluctuated for reasons touched upon at the end of the previous section. The 2008 Global Financial Crisis (GFC) caused the share price to tumble from 582p down to $240 \mathrm{p}$ (down $58.8 \%$ ), they have never recovered to prices that high. In fact, if a trend line is drawn from 2008 to present on a diagram of SBRY share price, it would have a negative gradient.

Compiled using researched data we can observe: the firm's revenues increased from 2017 to 2019 despite significant market uncertainty arising from failing Brexit deals, changes in tariffs all over the world, and a weakened Sterling. However, the increase in revenue from 2018 to 2019 is only $24.7 \%$ of the increase from 2017 to 2018, and revenue decreased from 2019 to 2020 , coupled with the decreasing market share, could imply that the company is in trouble, suggesting that it may not be worth investing in at the moment. The post-tax profits are falling at a rapid rate, too, a 59.7\% fall since 2017 . However, this is likely to be caused by $£ 396$ million of cash being set aside for the merging with ASDA that was blocked by competition authorities. In 2018, Sainsbury's also had to write off $£ 628$ million in impairment losses. Their earnings per share (a measure commonly used by investors to judge how profitable an investment is) fell by 69 p to $£ 18.24$, as shown in Table 1.

Table 1. Sainsbury's financial data 2017-2020 created using annual financial reports from 2020 and 2017 and dividends information from Hargreaves Lansdown

\begin{tabular}{ccccc}
\hline Year & 2020 & 2019 & 2018 & 2017 \\
\hline Revenue & $£ 28,993,000,000$ & $£ 29,007,000,000$ & $£ 28,456,000,000$ & $£ 26,224,000,000$ \\
Profit after tax & $£ 152,000,000$ & $£ 219,000,000$ & $£ 309,000,000$ & $£ 377,000,000$ \\
Borrowing & $£ 1,296,000,000$ & $£ 950,000,000$ & $£ 1,602,000,000$ & $£ 172,000,000$ \\
Market share & $15 \%$ & $15.3 \%$ & $16.2 \%$ & $16.4 \%$ \\
$\begin{array}{c}\text { SBRY Share Price } \\
\text { (at the start of the } \\
\text { year) }\end{array}$ & share price: $252.9 \mathrm{P}$ & $275.8 \mathrm{P}$ & $241.4 \mathrm{P}$ & $249.3 \mathrm{P}$ \\
$\begin{array}{c}\text { Dividends (per } \\
\text { share) }\end{array}$ & ) & & & \\
$\begin{array}{c}\text { Dividend Yield } \\
\text { (dividends per } \\
\text { share/initial share } \\
\text { price) to 1DP }\end{array}$ & $4.7 \%$ & $11.0 \mathrm{P}$ & $10.2 \mathrm{P}$ & \\
\hline
\end{tabular}

Dividends payments increased in the past year from a stationary $10.2 \mathrm{P}$ to $11 \mathrm{P}$ and fall to 10.5 in 2020. However, there was an increase in dividend yield in 2020, and a $4.7 \%$ dividend yield is a respectable amount, considering the best savings account on offer at the time of writing this is $1.75 \%$ (this is using initial share prices at the start of the respective years and not mean, so results will vary depending on the method used).

\subsection{Statement of Financial Position}

Their Statement of Financial Position states that the sum of their total assets to $£ 27.988$ billion, of which $£ 0.994$ billion in cash and their total liabilities sum to $£ 20.164$ billion, of which $£ 1.296$ billion are borrowings.

The company has $3.6 \%$ of its assets as cash, which can be viewed as a positive, capital intensive firms (firms that need to spend a lot to keep the business going) like
Sainsbury's need large quantities of cash as they are constantly having to restock goods and buy equipment in vast quantities for most of their stores. So, maintaining a healthy cash balance is integral to their survival. On the other hand, the large cash reserves could be viewed negatively. Perhaps the management team is not able to find a good investment for the firm, worried about a possible increase in importing costs due to Brexit or simply maintaining that amount of cash just for their egos ('Principle-Agent problem'), ensuring that they have something positive to say if they move a job to somewhere else. One thing we have to be wary of is the opportunity cost of capital. All of that cash held in the bank is not earning much interest. If Sainsbury's can invest the cash in a project for a rate of return greater than the interest rate, we can say that there will be an 'economic loss' from keeping significant amounts of cash. The borrowings account for $6.4 \%$ of the total 
liabilities, quite a low proportion for a firm in such a competitive market.

On 7th November 2019, Sainsbury's released a statement notifying that $90 \%$ of their profits have been lost due to a $£ 200$ million cost of closing stores. The result of this fall in profits is extremely likely to lead to further lower share prices.

Sainsbury's has also announced that it shall close down 125 stores over the next 5 years, and this does not include Argos stores closing down which Sainsbury's owns, the closures shall comprise of 110 local branches and 10 supermarkets, 5 more are earmarked too. This may lead to a decrease in its future market share and longterm profit.

\subsection{Comparison}

We used different ratios and compared them with those of other competitors. Sainsbury's is the second biggest retailer in the UK, and therefore we will compare it with the biggest retailer, Tesco. According to table 2, these two companies' share prices are almost equivalent. Therefore, the company with a better profitability ratio tends to perform better. The profitability ratio (GP/Asset) for Sainsbury's is $7.22 \%$, while Tesco's profitability ratio is $8.94 \%$, which is higher than that of Sainsbury's.

Since the share outstanding in different companies is different, the growth rate of EPS is usually used for comparison. Unfortunately, because of the Covid-19, the EPS of the two companies had a relatively large decline compared with last year, with almost equal growth rates. Sainsbury's $\mathrm{P} / \mathrm{E}$ ratio is much higher than Tesco. This usually indicates that the company's stock is more expensive. As of the average EV/EBITDA for S\&P 500 was 14.20. as a general benchmark, an EV/EBITDA value below 10 is commonly interpreted as healthy. Therefore, these two companies' EV multiples are considered healthy indicators.

Sainsbury's has a higher dividend yield than Tesco. However, a higher dividend yield does not always indicate an attractive investment opportunity because the dividend yield of a stock may be elevated as the result of a declining stock price.

Table 2. Value investing data for Sainsbury's and Tesco

\begin{tabular}{lll}
\hline & Sainsbury's & Tesco \\
\hline Share price & 252.9 pence & 244.9 pence \\
P/E & 38.53 & 23.78 \\
EV/EBITDA & 6.51 & 8.94 \\
GP/ASSET & $7.22 \%$ & $8.76 \%$ \\
Dividend yield & $4.91 \%$ & $4.27 \%$ \\
\hline
\end{tabular}

\begin{tabular}{lll}
\hline Growth rate of & $-23.68 \%$ & $-23.91 \%$ \\
EPS & & \\
\hline
\end{tabular}

\subsection{Estimated Future Performance}

After the ASDA - merger failed, Sainsbury's decided to focus on reducing debt and core business investment. CEO of Sainsbury's, Mike Coupe said, the next steps are carrying on reducing net debt and improve both online and actual stores. It is a conservative decision as well as good news for investors, because the announcement shows that they are concentrating on internal development, which is much less risky than external expansion like a merger.

Market movements are more a study of psychology and "animal spirits" than applied finance, amplified by most extensive quantitative easing program (QE). Unprecedented central bank easing/stimulus (QE) started with the 2008 credit crisis and jumped in 2020 to offset Covid-19 pandemic-driving stocks/bond price higher $\&$ interest rates to record low levels. Quantitative analysis shows that the performance of the company has not been satisfactory in recent years, but the stock price has risen rapidly due to $\mathrm{QE}$. We have reason to worry that there might be a bubble in the stock market.

Macroeconomically, there were people believing The UK economy was already in a recession period. From Figure 3 , we can find that there was a dramatically increasing growth of Gross Domestic Product (GDP) from 2010 to 2019. Although it greatly declined in the first half of 2020 due to the Covid-19, the GDP of the UK is recovering rapidly since May. John Hawksworth, chief economist of PwC, suggested that although recession was not through the UK, he would be extremely prudent since the uncertainty generated by Brexit is still increasing.

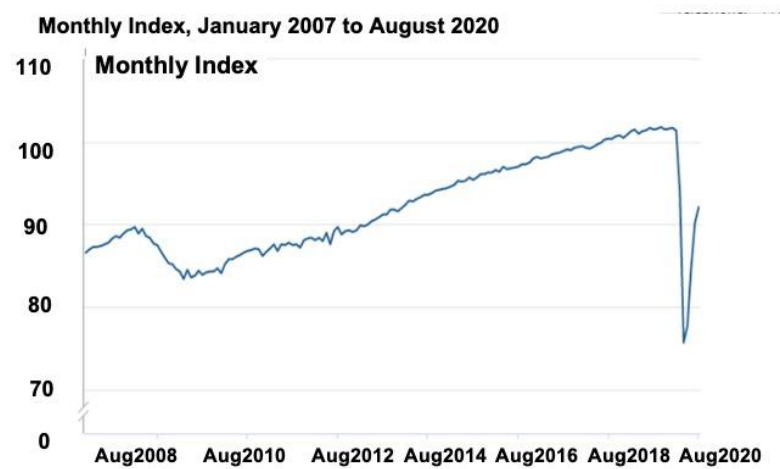

Figure 3. UK GDP movement from Aug 2008 to Aug 2020.

\section{CONCLUSION}

According to SWOT analysis, Sainsbury's was not doing so good in 2020. The internal-development strategy benefits investors since internal development usually means that more wealth will be distributed in the 
form of dividends. However, as uncertainties of Brexit continue to spread, unless Sainsbury's could publicly announce that they find a way to solve any potential problem caused by Brexit, nobody can assert that Sainsbury's has a promising future. During the pandemic, Sainsbury's vigorously developed its online business, but this did not make this firm benefit more from it. Instead, Sainsbury's has lost some market share compared with the companies with mature online shopping systems that have gained huge profits. In the analysis of financial data, we compared Sainsbury's current performance with historical data and its biggest competitor's performance. Historically, the company's market share has been consistently dropping. The company's profit is also decreasing year by year. However, the debt has been increasing, which leads to the company's leverage ratio becoming higher, increasing the risk of investment. Through comparison, it is easy to find that Sainsbury's is less valuable for investing than Tesco, because their share prices are similar, but Sainsbury's performance in 2020 is worse. Therefore, the company is less likely to be undervalued. Therefore, currently, the article suggests that future uncertainties and threats of Sainsbury's outweigh its opportunities.

In theory, what this paper wants to convey is that value investors should not follow the herd. Even now the stock market price has reached a new height because of QE. We still need to pay more attention to the intrinsic value rather than the stock price. Trendy stocks are likely to be overpriced. In practice, through the systematic and profound analysis of the company, this paper gives investors appropriate investment advice. Although the company has done well in some aspect, compared with the previous performance and peer performance, it has not met our expectations. In addition, the epidemic and Brexit have a huge impact on the whole industry. To be a rational investor, it is not a good time to invest it. For Sainsbury's, this article is a good list of its current disadvantages and potential threats in the future. This can give the enterprise a good direction to improve and avoid these potential threats. At the same time, data analysis shows that the company's business situation is deteriorating. It must optimize the industrial structure and make strategic adjustments for various problems, which can further occupy more market share and achieve better profitability. The world stock market has recovered from the great fall of the pandemic and reached a much higher level. However, whether the UK economy will enter a recession is uncertain for us. More evidence is needed to support this conjecture.

\section{REFERENCES}

[1] Graham, B., Dodd, David L., Security Analysis, New York: McGraw Hill Book Co., 1934.

[2] Petrova E. Value investing-essence and ways of finding undervalued assets[C]//International conference

KNOWLEDGE-BASED

ORGANIZATION. Sciendo, 2015, 21(2): 344-348.

[3] Moore G, Robson A. The UK supermarket industry: an analysis of corporate social and financial performance[J]. Business Ethics A European Review, 2010, 11(1):25-39.

[4] Shen Y. How to Improve Customer Loyalty to Online Travel Agencies: A research on Expedia, an online travel booking platform[J]. 2018

[5] Rejaul K M, Nazmul H K, Sultana K R. Significance of Training and Post Training Evaluation for Employee Effectiveness: An Empirical Study on Sainsbury's Supermarket Ltd, UK[J]. International Journal of Business and Management, 2012, 7(18).

[6] Robinson N. Sainsbury's own-label lines boost food sales[J]. Meat Trades Journal, 2013, 10(12).

[7] Fearne A, Duffy R, Hornibrook S. Justice in UK Supermarket Buyer-Supplier Relationships[J]. International Journal of Retail \& Distribution Management, 2005, 33(8/9):570-582.

[8] JIN Bei. On Organizational Capital and Organizational Policy of the Economy Enlightenment from the Epidemic Situation of COVID-19 [J]. China Industrial Economics, 2020, No.385 (04): 25-43.

[9] Weber J M, Calvi L M. Sainsbury: can it be resuscitated? Sales at Sainsbury, once Britain's proudest supermarket, are flatlining. There are signs that chief executive Justin King is breathing new life into the business. But is he applying the right treatment to restart its pul [J]. Bone, 2010, 46(2):281-5.

[10] Antuo $\mathrm{Xu}$. The Possible Impact of Brexit on the Global Economy [J]. People's Tribune, 2016 (7): 2830 